\title{
Live attenuated measles virus vaccine therapy for locally established malignant glioblastoma tumor cells
}

This article was published in the following Dove Press journal:

Oncolytic Virotherapy

3 May 2014

Number of times this article has been viewed

\author{
Ahmed M Al-Shammari' \\ Farah E Ismaeel ${ }^{2}$ \\ Shahlaa M Salih ${ }^{2}$ \\ Nahi Y Yaseen' \\ 'Experimental Therapy Department, \\ Iraqi Center for Cancer and Medical \\ Genetic Researches, Mustansiriya \\ University, ${ }^{2}$ Departments of \\ Biotechnology, College of Science, \\ Al-Nahrain University, Baghdad, Iraq
}

\begin{abstract}
Glioblastoma multiforme is the most aggressive malignant primary brain tumor in humans, with poor prognosis. A new glioblastoma cell line (ANGM5) was established from a cerebral glioblastoma multiforme in a 72-year-old Iraqi man who underwent surgery for an intracranial tumor. This study was carried out to evaluate the antitumor effect of live attenuated measles virus (MV) Schwarz vaccine strain on glioblastoma multiforme tumor cell lines in vitro. Live attenuated MV Schwarz strain was propagated on Vero, human rhabdomyosarcoma, and human glioblastoma-multiform (ANGM5) cell lines. The infected confluent monolayer appeared to be covered with syncytia with granulation and vacuolation, as well as cell rounding, shrinkage, and large empty space with cell debris as a result of cell lysis and death. Cell lines infected with virus have the ability for hemadsorption to human red blood cells after 72 hours of infection, whereas no hemadsorption of uninfected cells is seen. Detection of MV hemagglutinin protein by monoclonal antibodies in infected cells of all cell lines by immunocytochemistry assay gave positive results (brown color) in the cytoplasm of infected cells. Cell viability was measured after 72 hours of infection by 3-(4,5-Dimethylthiazol-2-yl)-2,5-diphenyltetrazolium bromide assay. Results showed a significant cytotoxic effect for MV $(P \leq 0.05)$ on growth of ANGM5 and rhabdomyosarcoma cell lines after 72 hours of infection. Induction of apoptosis by MV was assessed by measuring mitochondrial membrane potentials in tumor cells after 48, 72, and 120 hours of infection. Apoptotic cells were counted, and the mean percentage of dead cells was significantly higher after 48, 72, and 120 hours of infection compared with control cells. This study concludes that live attenuated MV Schwarz vaccine induces the oncolytic effect in Iraqi tumor cell line ANGM5 and in the rhabdomyosarcoma cell line through syncytia in tumor cells, which is one of the causes of cell death. The MV vaccine strain has the ability to insert its hemagglutinin protein into the tumor cell surface, leading to modification of the antigenic surface of tumor cells that may induce an antitumor immune response, MV vaccine strain induced cell killing by direct cytolysis and apoptosis induction. These antitumor features may indicate the use of MV in the treatment of glioblastoma.
\end{abstract}

Keywords: virotherapy, glioblastoma multiforme

\section{Introduction}

Glioblastomas (GBMs) are the most frequent primary tumors of the central nervous system in humans, involving glial cells and accounting for $52 \%$ of all functional tissue brain tumor cases and $20 \%$ of all intracranial tumors. ${ }^{1}$ During the last 2 decades, the paradigm for cancer treatment has developed from relatively nonspecific cytotoxic agents to selective, mechanism-based therapeutics. ${ }^{2}$ Targeted approaches aim to inhibit molecular pathways that are crucial for tumor growth
Correspondence: Ahmed M Al-Shammari Department of Experimental Therapy, Iraqi Center for Cancer and Medical Genetic Research, PO Box 15007 Al-Yarmook Post Office, Baghdad, Iraq Tel +9647809l43825

Email ahmed.alshammari@iccmgr.org 
and maintenance. ${ }^{3}$ Oncolytic viruses are defined by their ability to specifically target tumor cells while leaving the normal tissues safe. Their most characteristic features are their target selectivity and their cytolytic capacity, as well as the ability to recruit uninfected neighboring cells (syncytia formation), the ability to infect dividing and nondividing cells, a high stability in vivo, the inability to perform chromosomal integration, and the lack of disease induction. ${ }^{4}$ Numerous viruses are now being considered as potential cancer therapeutics, including the vaccine strain of measles virus (MV). MV is an envelope and negative, nonsegmented, single-strand RNA virus belonging to the Morbillivirus genus of the Paramyxoviridae family. ${ }^{5}$ The attenuated strain of measles readily lyses transformed cells, whereas replication and lysis are limited in normal human cells. It has a number of features that make it highly suitable for further development as an oncolytic agent, among them stability and a long history of safety in human use. These features are being combined with its ready potential for genetic manipulations to generate recombinant MVs with desirable therapeutic attributes. ${ }^{6}$ Peng et al reported that a growing interest in onco-virotherapy, using a number of replication-competent (oncolytic) viruses such as MV for cancer therapy, has emerged. ${ }^{7}$ Previous studies have proved that different MV strains demonstrated potent oncolytic efficacy with minor or no adverse effects against multiple primary and established cancer cell lines and several preclinical animal tumor models, including both solid tumors and hematologic malignancies such as ovarian cancer. Zhang et al showed that a large variety of oncolytic viruses have been engineered, and among the many oncolytic virus systems, the attenuated Edmonston vaccine strain of the MV has proven safe and effective. ${ }^{8}$ Al-Shamery et al concluded that the Iraqi strain of Newcastle disease virus had the ability to replicate in different cell types of tumors and to insert their $\mathrm{H}$ protein in the tumor cell surface that leads to modifying the antigenic determinants and increasing the immunogenicity of the tumor cell surface. Thus, the modification of tumor induces the attachment of CD4 and CD8 T cells on an infected tumor cell surface. ${ }^{9}$ Another study of Al-Shamery et $\mathrm{al}^{10}$ revealed that Iraqi strain of Newcastle disease virus, when used as an oncolytic agent by intratumoral injection, showed a significant stimulation in immune response by increasing the level of interleukin 2 and interferon $\gamma$ and increasing the percentage of CD8 and CD56 cell in tumor sections. ${ }^{10}$ This study aims to investigate the oncolytic ability of measles vaccine strain on a GBM tumor cell line derived from an Iraqi patient.

\section{Methods}

\section{Live attenuated virus vaccine against measles (Schwarz strain)}

Schwarz strain (Aventis Pasteur SA, Lyon, France) was obtained by personal communication.

\section{Cell culture}

The GBM multiform (ANGM5) cell line was supplied by the Iraqi Center for Cancer and Medical Genetic Researches (ICCMGR). The patient from whom the tumor was derived was a 72-year-old man who was admitted to the neurosurgery hospital in 2005 in Baghdad, Iraq. The patient presented with left-sided hemipareses of 1 month's duration, with headache and blurred vision. The patient did not receive chemotherapy or radiation therapy before the operation. A magnetic resonance imaging scan showed a right parieto-occipital mass, which was then resected. A tumor specimen $\left(1.5 \mathrm{~cm}^{3}\right)$ was excised and used to establish the cell line. The pathological diagnosis was GBM multiforme, based on the histological features of vascular proliferation, hypercellularity, high mitotic index, gemistocytic nuclei, and necrosis. Al-Shamery et al proved the GBM cell line (ANMG5) was resistant to chemotherapy.,11

Vero (African green monkey) cell line and human rhabdomyosarcoma (RD) cell lines were supplied by ICCMGR, cell bank unit; these cells, including ANGM5, were grown at $37^{\circ} \mathrm{C}$ in Roswell Park Memorial Institute medium, as recommended by ICCMGR. All media contained $200 \mathrm{U} / \mathrm{mL}$ penicillin and $100 \mathrm{U} /$ $\mathrm{mL}$ streptomycin and were supplemented with $10 \%$ fetal bovine serum (Cellgro, Manassas, VA USA), according to cell types.

\section{MV propagation}

MV was propagated by infecting $1.5 \times 10^{6}$ Vero cells in T25 flasks in $3 \mathrm{~mL}$ serum-free Minimum Essential Medium (MEM; US Biological, Salem, MA, USA) at $37^{\circ} \mathrm{C}$ for 2 hours, and then the medium was replaced with serum-free media. The cells were incubated at $37^{\circ} \mathrm{C}$ for $3-5$ days and subsequently harvested in $1 \mathrm{~mL}$ MEM (US Biological). The viruses were then released by three cycles of freezing and thawing. The titers of viral stocks were determined by $50 \%$ end-point dilution assays on Vero cells in 96-well plates.

\section{Studying the cytopathic effect of MV and hemadsorption test}

\section{Cell seeding}

Cancer cells (RD and ANGM5) and Vero cells were dispersed with trypsin-ethylenediaminetetraacetic acid (US Biological) and suspended in growth media with $10 \%$ fetal calf serum, and $1-3 \mathrm{~mL}$ cell suspension $\left(1 \times 10^{5}\right.$ cells/dish) was seeded 
in plastic tissue culture Petri dishes that contain sterile cover slips. Cells were incubated at $37^{\circ} \mathrm{C}$ for 24 hours or until a confluent monolayer formed. ${ }^{12}$

\section{Cell infection}

The procedure of infection with MV was carried out by removing the old media that contain serum and adding $1 \mathrm{~mL}$ of the virus solution (concentrated inoculums $=3.4 \times 10^{5}$ ) for 2 hours at room temperature, with shaking, to allow virus attachment and penetration. After that, cells were washed with phosphate-buffered saline (PBS), and serum-free medium was added. Cells were incubated for 3 days or until cytopathic effect appeared. ${ }^{13}$

\section{Preparation of I\% human red blood cell solution}

Blood was collected from healthy persons in a heparinized tube and washed three times with PBS by centrifugation at $1,000 \mathrm{rpm}$ at $4^{\circ} \mathrm{C}$, the supernatant was discarded, $0.1 \mathrm{~mL}$ cell pellet was transferred to a sterile graduated tube, and the volume was completed to $10 \mathrm{~mL}$ with PBS. ${ }^{14}$ Hemadsorption of cell culture infected with MV was carried out according to Haas et al. ${ }^{15}$ RD, GBM, and Vero cell line infected with MV were washed three times with PBS after removing the old

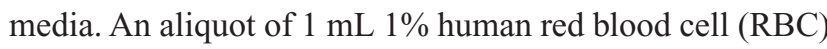
solution was added to cell sections. Cells were incubated with the $\mathrm{RBC}$ solution for 30 minutes at $4^{\circ} \mathrm{C}$ and then washed two times with PBS to remove nonadsorbed RBCs. Finally, adsorbed RBCs were fixed by adding $1 \mathrm{~mL} \mathrm{4 \%} \mathrm{formaldehyde}$ and cells incubated for 30 minutes at $4{ }^{\circ} \mathrm{C}$. This experiment was done in the presence of control groups of cancer cells not infected with MV.

\section{Hematoxylin and eosin staining}

Cell sections were immersed in hematoxylin solution for 5 minutes and washed in distilled water for three changes. Then cell sections were immersed in eosin solution for 2-3 minutes. Cell sections were dehydrated by being immersed in $95 \%$ alcohol for 1 minute, and then two changes were made in absolute alcohol for 2 minutes each. Clearing was made by adding xylene for 1 minute, and then absolute alcohol was added for 2 minutes to remove xylene. Finally, cell sections were mounted with xylene-based mounting medium.

\section{Detection of MV hemagglutinin protein}

This was done by using immunoperoxidase kit for staining of cell lines infected with MV. Measles hemagglutinin
(H; 6016) is a monoclonal antibody against the Edmonston strain of MV. The principle of the test is that the primary antibody (monoclonal antibody) binds to the $\mathrm{H}$ protein of $\mathrm{MV}$, and the secondary antibody binds to determinants on the primary antibody. Then the avidin containing the horseradish peroxidase enzyme was allowed to bind to the biotin molecule attached to the secondary antibody. The staining procedure was done as recommended by the manufacturer (Santa Cruz Biotechnology, Dallas, TX, USA).

\section{Studying the oncolytic effect of MV on RD and GMB}

For cell viability assays, $7 \times 10^{3}$ cells $/ 50 \mu \mathrm{L}$ were plated into 96-well plates and infected with the live-attenuated MV vaccine at twofold dilution. At the end of the incubation period, the virus was removed, and the cells were maintained in serum-free media. At 1, 2, 3, 4, and 5 days after infection, cell viability was determined by the MTT (3-(4,5Dimethylthiazol-2-yl)-2,5-diphenyltetrazolium bromide) assay. That measures the formation of insoluble formazan by mitochondria in viable cells. The reaction was subsequently discontinued by lysing the cells with $200 \mu \mathrm{L}$ dimethyl sulfoxide for 15 minutes. Quantification measurements (optical density) were obtained at a wavelength of $550 \mathrm{~nm}$, using spectrophotometric analysis. ${ }^{12}$

\section{Apoptosis induction in vitro}

GBM cells (ANGM5), RD, and control cells were cultured in plastic tissue culture Petri dishes. After $70 \%$ confluence (18-24 hours), cells were infected with MV for 48, 72, and 120 hours. Each virus incubation period was done with three replicas.

Before use, MitoCapture ${ }^{\mathrm{TM}}$ (US Biological) was diluted at a ratio $1: 1,000$ by mixing $1 \mu \mathrm{L}$ MitoCapture ${ }^{\mathrm{TM}}$ to $1 \mathrm{~mL}$ prewarmed incubation buffer and mixing well by vortex. MitoCapture $^{\mathrm{TM}}$ is poorly soluble in aqueous solutions. To remove nonsoluble particles, the dye solution was centrifuged for 1 minute at $13,000 \mathrm{rpm}$ and carefully transferred to the supernatant without disturbing pellet debris, and then $0.4 \mathrm{~mL}$ diluted MitoCapture ${ }^{\mathrm{TM}}$ solution was added to adherent cells and incubated at $37^{\circ} \mathrm{C}$ for $15-20$ minutes in the dark.

Cells were washed with prewarmed incubation buffer three times, and then $0.4 \mathrm{~mL}$ of the prewarmed incubation buffer was added.

Cells were examined immediately under a fluorescent microscope, using a band-pass filter (detects fluorescein and rhodamine). MitoCapture ${ }^{\mathrm{TM}}$ that has aggregated in the mitochondria of healthy cells gives off red light. In apoptotic 
cells, MitoCapture ${ }^{\mathrm{TM}}$ cannot accumulate in the mitochondria but remains as monomers in the cytoplasm and gives off green light.

The results were calculated by counting apoptotic cells and using Image J program version 1.47 (National Institutes of Health, Bethesda, MD, USA). This program is an image processing and analysis program that can create density histograms. It converted the images from MitoCapture ${ }^{\mathrm{TM}}$ to histograms by showing the number of pixels of each value, regardless of location, and the mean and maximum values. The log display allows for the visualization of minor components. ${ }^{16}$

\section{Statistical analysis}

A paired sample $t$-test was used within the SPSS program (version 20) for analysis of data. The difference was considered significant when $P \leq 0.05$.

\section{Results and discussion Cytopathic effect of MV on RD and GBM cell lines in vitro}

The typical cytopathic effect of MV was the formation of mononuclear cell aggregates (syncytia) caused by cell-cell fusion. ${ }^{17}$ The MV shows a high ability for
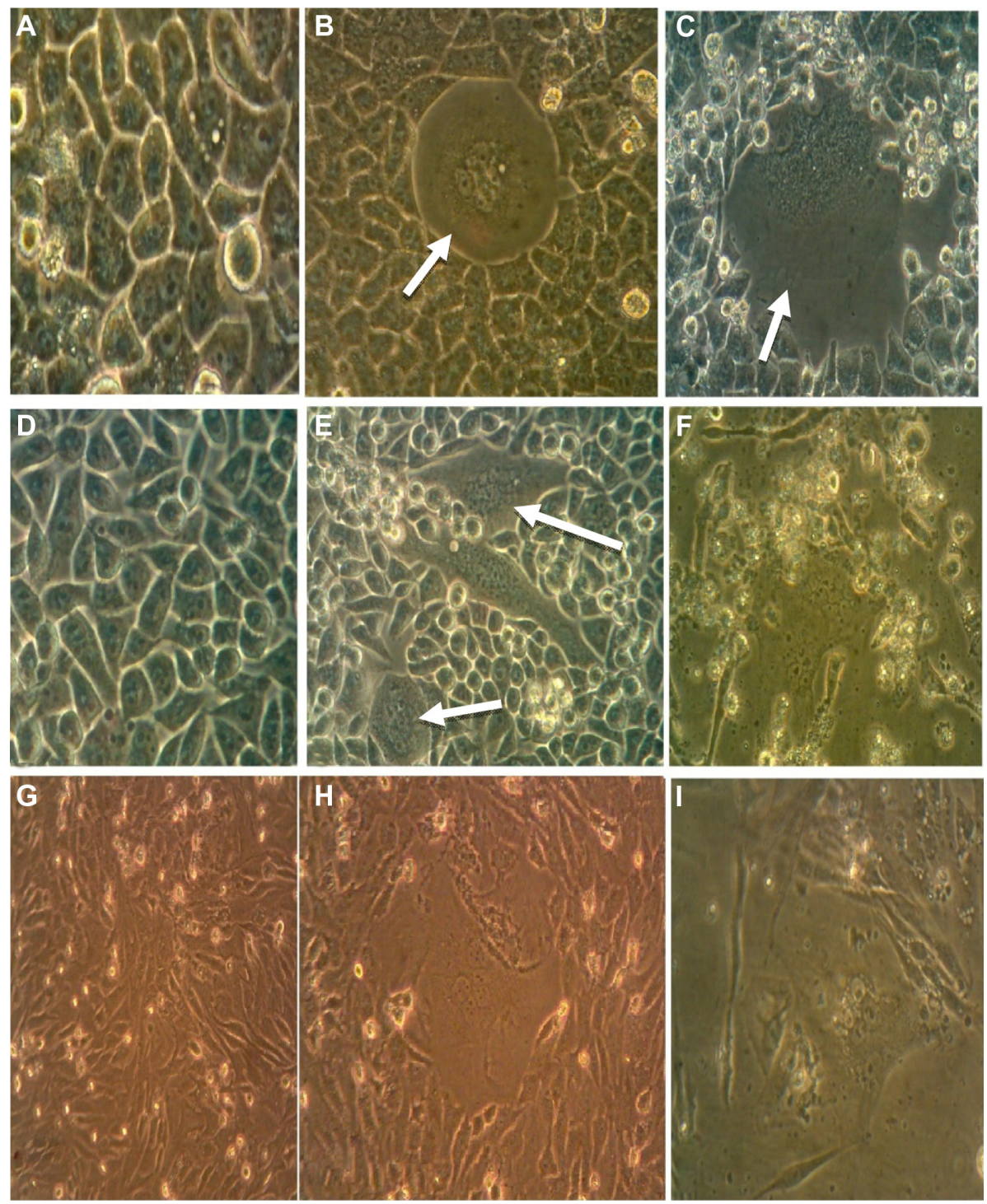

Figure I Propagation of measles virus on Vero, rhabdomyosarcoma (RD), and ANGM5 cell lines.

Notes: (A) Vero cell line uninfected with measles virus, 100x. (B) Vero cells infected with measles virus, showing syncytial formation and cell granulation after 72 hours of infection, 40×. (C) Vero cells infected with measles virus, showing syncytial formation and cell granulation after I20 hours of infection, 40×. (D) RD cell line uninfected with measles virus, 100×. (E) RD cell line infected with measles virus, showing syncytial formation and cell granulation after 72 hours of infection (arrows), 40×. (F) RD cell line infected with measles virus, showing syncytial formation and cell granulation after 120 hours of infection, 40X. (G) ANGM5 cell line uninfected with measles virus, 20X. (H) ANGM5 cell line infected with measles virus, showing syncytial formation and cell granulation after 72 hours of infection, 40X. (I) ANGM5 cell line infected with measles virus, showing syncytial formation and cell granulation after 120 hours of infection, $40 \times$. 
propagation and lysis of Vero cells. After 120 hours of exposure, alterations in the morphological characteristics of Vero cells were cell rounded shrinkage, clustered cells, and large empty space with cell debris as a result of cell lysis and death. Although no morphological alteration was observed in uninfected cells, MV shows the same effect on RD and GBM cells (Figures 1 and 2).

\section{Hemadsorption effect of MV}

Results showed that all cell lines (Vero, RD, and GBM) infected with virus have the ability for hemadsorption of human RBCs after 72 hours of infection, whereas uninfected cells gave negative results for hemadsorption (Figure 3).

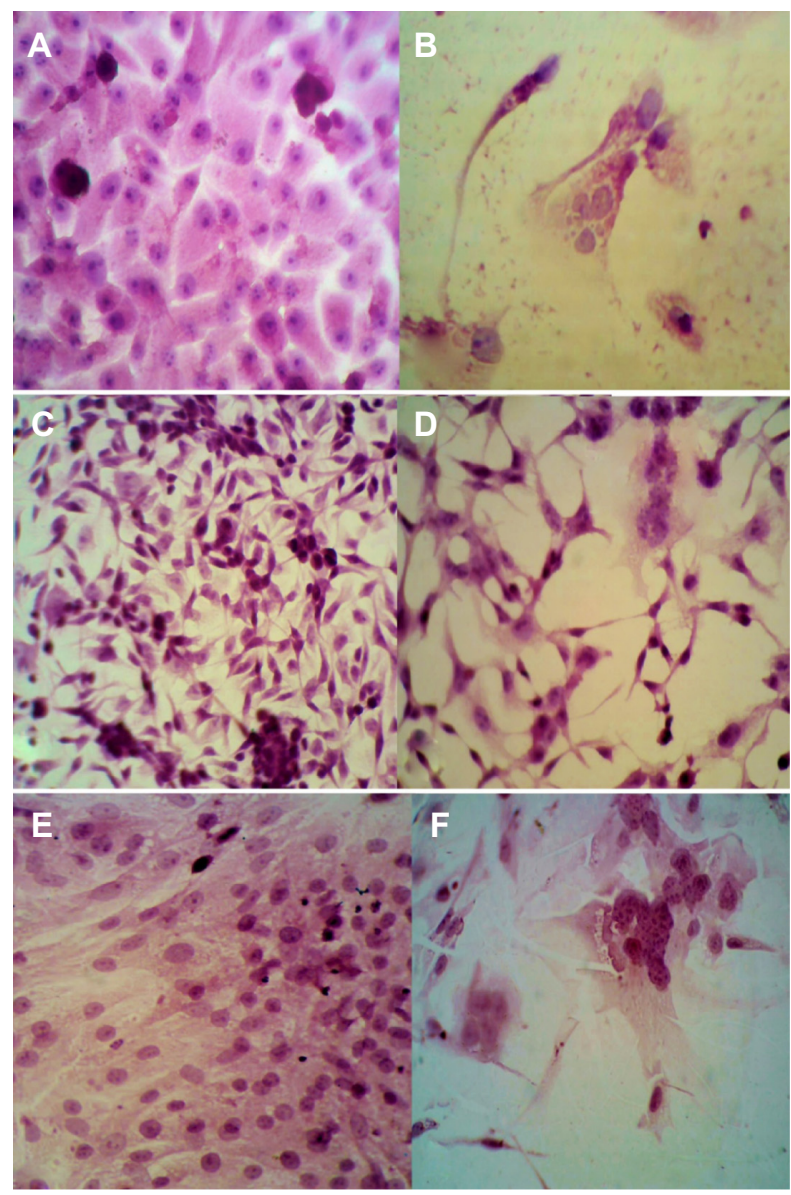

Figure 2 Cytopathic effect of measles virus on Vero and tumor cell lines in vitro.

Notes: (A) Vero cells uninfected with virus. (B) Vero cells showing syncytia formation and large empty space with cell debris after I 20 hours of measles virus infection. (C) Rhabdomyosarcoma cells uninfected with virus. (D) Rhabdomyosarcoma cells showing syncytia and large empty space with cell debris after 120 hours of measles virus infection. (E) Glioblastoma cells uninfected with virus. (F) Glioblastoma cells showing syncytia and large empty space with cell debris after I 20 hours of measles virus infection.

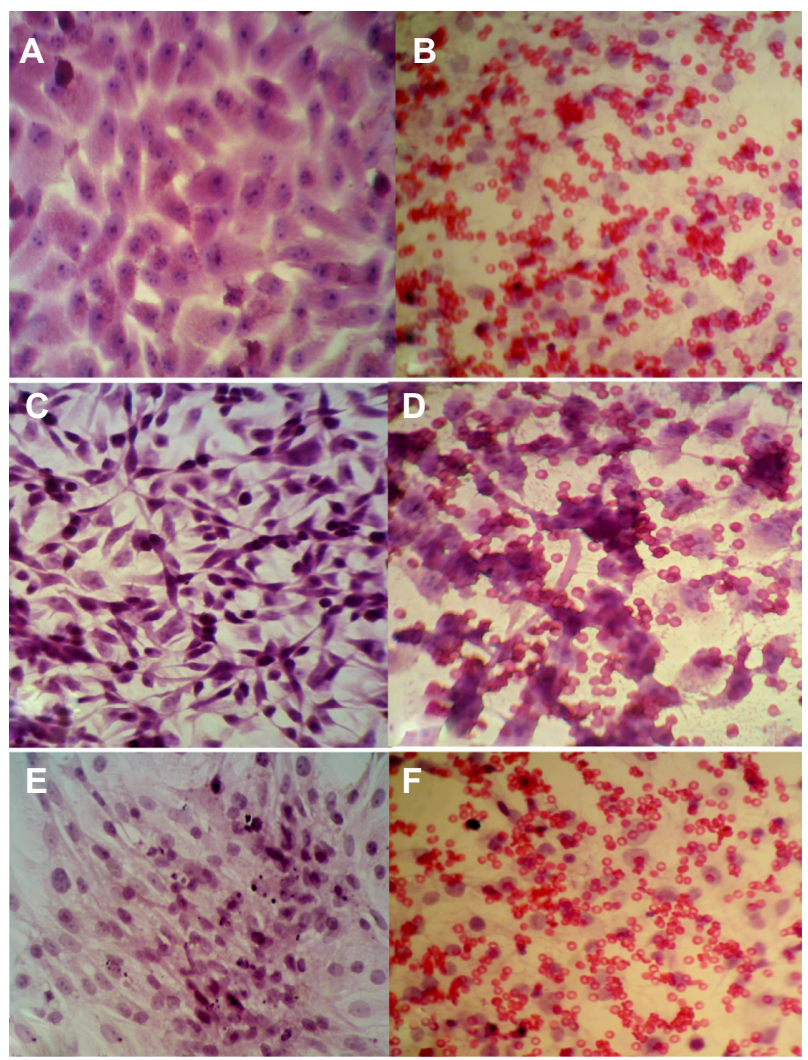

Figure 3 Hemadsorption effect of measles virus on Vero and tumor cell lines.

Notes: (A) Vero cells uninfected with measles virus and treated with human red blood cells (RBCs). (B) Hemadsorption of human RBCs on Vero cells after 72 hours of measles virus (MV) infection. (C) Rhabdomyosarcoma (RD) cells uninfected with measles virus and treated with human RBCs. (D) Hemadsorption of human RBCs on RD cells after 72 hours of $M V$ infection. (E) Glioblastoma cells uninfected with virus and treated with human RBCs. (F) Hemadsorption of human RBCs on glioblastoma cells after 72 hours of MV infection. Hematoxylin and eosin staining, 40x.

\section{Detection of MV H protein in infected cell lines}

Monoclonal antibodies specific for $\mathrm{H}$ protein of MV in Vero, RD, and GBM cell lines after 72 and 120 hours of virus infection showed that $\mathrm{H}$ protein was found in the cytoplasm of infected cells, appearing as a stained brown color; uninfected cell cytoplasm was negative-stained. The nuclei of infected and uninfected cells both gave off a blue color (Figures 4-6).

\section{Cytotoxic effect of MV on RD and GBM}

Results in Figure 7 showed a significant cytotoxic effect for MV $(P \leq 0.05)$ on the growth of the RD cell line at the first and second dilution, with a growth inhibition percentage of $56.778 \%$ and $60.439 \%$, respectively, after 72 hours of infection. When the dilution increased, there was a significant decline in the inhibitory effect, with a significant cytotoxic effect when compared to the control (displaying growth inhibition percentages of $38.616 \%, 31.039 \%$, and $19.801 \%$, respectively). In 

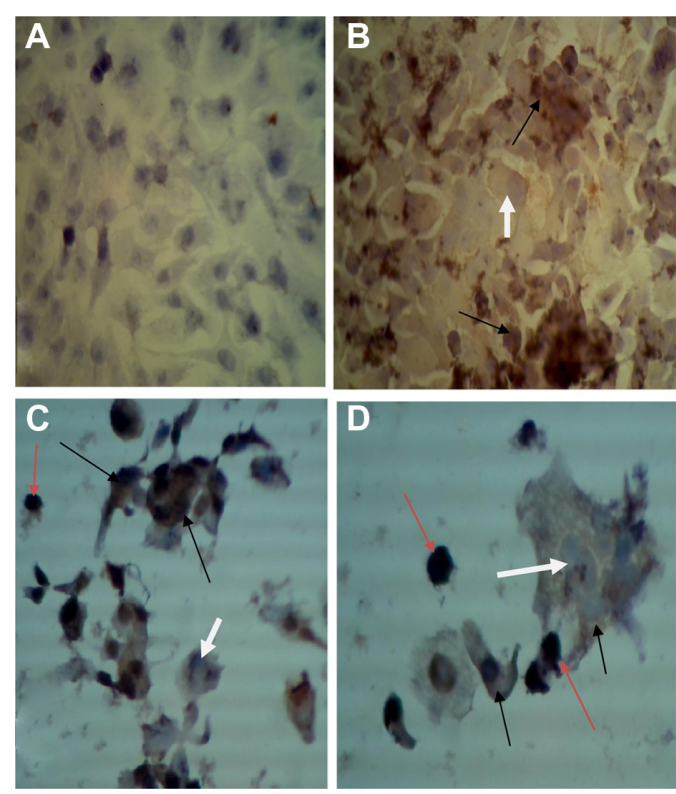

Figure 4 Detection of measles virus (MV) hemagglutinin protein in Vero cell line. Notes: (A) Cytoplasm of uninfected Vero cells showing no color, with blue nuclei, 40×. (B) Cytoplasm of Vero cells infected with MV, showing brown color and blue nuclei after 72 hours of infection, $40 \times$. (C) Cytoplasm of Vero cells showing brown color (black arrows), blue nuclei (white arrows), and dead cells with black color (red arrows) after 120 hours of infection, 40×. (D) Vero cells infected with MV for 120 hours; cell cytoplasm is stained brown, nucleus is stained blue, 100x.
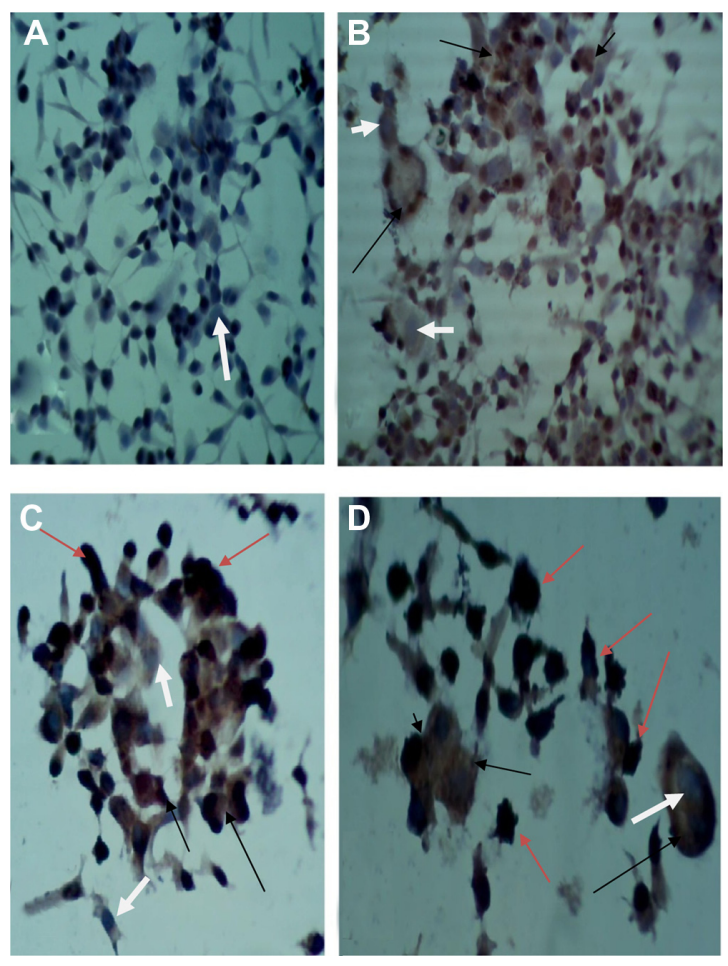

Figure 5 Detection of measles virus hemagglutinin protein in the rhabdomyosarcoma (RD) cell line.

Notes: (A) Cytoplasm of uninfected RD cells showing no color with blue nuclei, $40 \mathrm{x}$. (B) Cytoplasm of RD cells infected with measles virus, showing brown color and blue nuclei after 72 hours of infection, 40x. (C) Cytoplasm of RD cells showing brown color (black arrows), blue nuclei (white arrows), and dead cells with black color (red arrows) after 120 hours of infection, 40×. (D) Cytoplasm of RD cells showing brown color (black arrows), blue nuclei (white arrow), and dead cells with black color (red arrows) after 120 hours of infection, 100x.
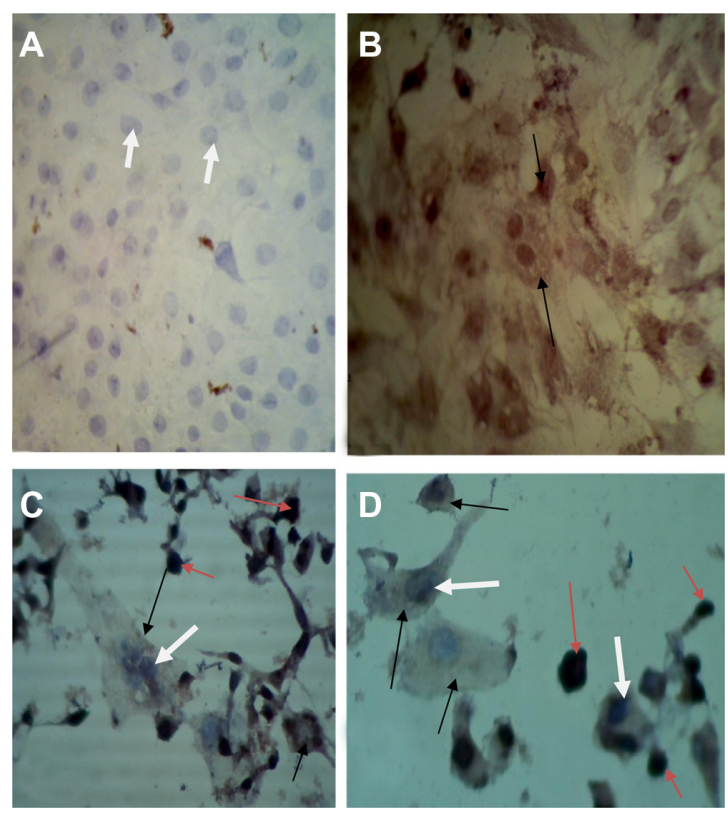

Figure 6 Detection of measles virus hemagglutinin protein in glioblastoma (GBM) cell line.

Notes: (A) Cytoplasm of uninfected GBM cells showing no color with blue nuclei, 40×. (B) Cytoplasm of GBM cells infected with measles virus showing brown color and blue nuclei after 72 hours of infection, 40×. (C) Cytoplasm of GBM cells showing brown color (black arrows), blue nuclei (white arrows), and dead cells with black color (red arrows) after 120 hours of infection, 40x. (D) Cytoplasm GBM cells showing brown color (black arrows), blue nuclei (white arrows), and dead cells with black color (red arrows) after 120 hours of infection, 100x.

addition, concentrated inoculums of MV showed a significant cytotoxic effect when compared with the control; growth inhibition percentage was $41.298 \%$, as shown in Figure 7.

Results in Figure 8 showed the cytotoxic effect of MV on RD cells after 120 hours of infection. A significant cytotoxic effect $(P \leq 0.05)$ on the growth of the RD cell line was seen at dilutions 1, 2, and 3 when compared with the control, with a growth inhibition percentage of $53.110 \%, 69.954 \%$, and $53.717 \%$, respectively. A concentrated inoculum of MV showed a significant cytotoxic effect when compared with the control, with a growth inhibition percentage of $13.050 \%$. The cytotoxic inhibition rate was significantly decreased when the dilution increased. There were significant effects at dilutions 4,5 , and 6 , with a growth inhibition percentage of $31.714 \%, 15.174 \%$, and $5.918 \%$, respectively.

The MV had a significant effect on GBM cells after 72 hours of exposure when compared with the control at dilutions 1,2 , and 3 , with a growth inhibition percentage of $46.047 \%, 73.183 \%$, and $58.012 \%$, respectively. A significant decrease in cytotoxic inhibition rate was recorded when the dilution increased, with a significant cytotoxic effect at dilutions 4, 5, and 6, with percentage of growth inhibition at $27.350 \%, 19.658 \%$, and $14.529 \%$, respectively. A concentrated inoculum of MV showed a significant cytotoxic effect when compared with the control, with a growth inhibition percentage of $46.047 \%$, as shown in Figure 9. 


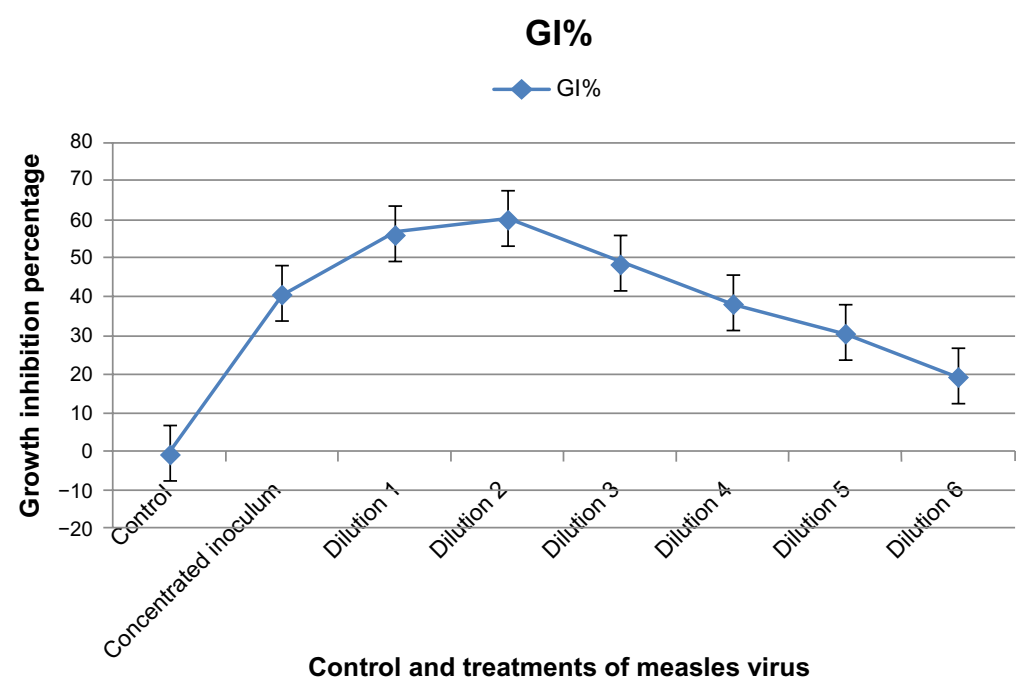

Figure 7 Cytotoxic effect of concentrated and diluted inoculum of measles virus on rhabdomyosarcoma cell line after $\mathbf{7 2}$ hours of infection. Abbreviation: GI\%, growth inhibition percentage.

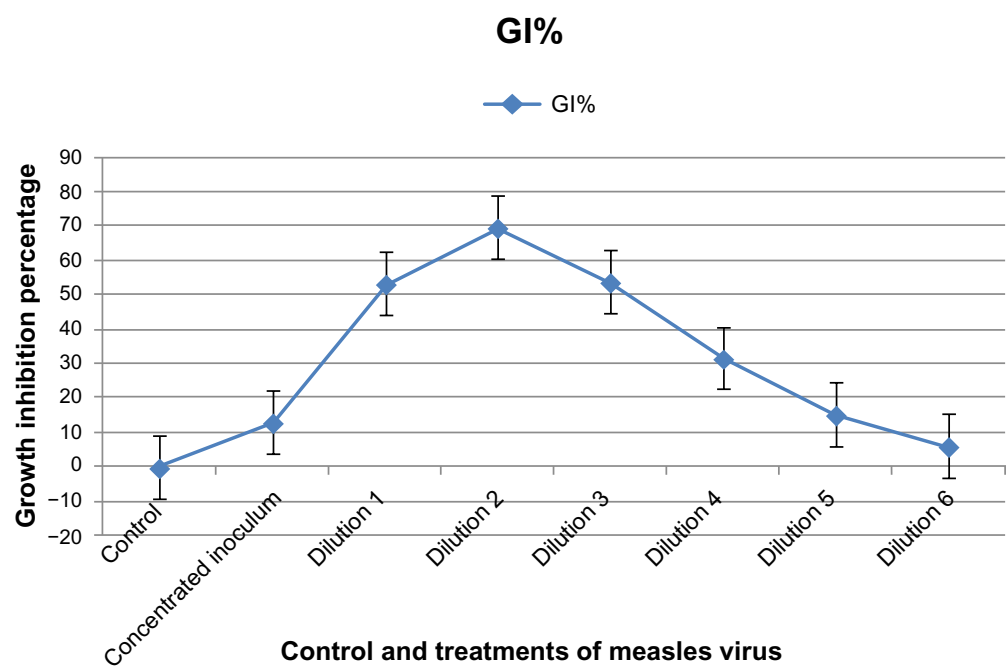

Figure 8 Cytotoxic effect of concentrated and diluted inoculum of measles virus on the rhabdomyosarcoma cell line after 120 hours of infection. Abbreviation: $\mathrm{Gl} \%$, growth inhibition percentage.

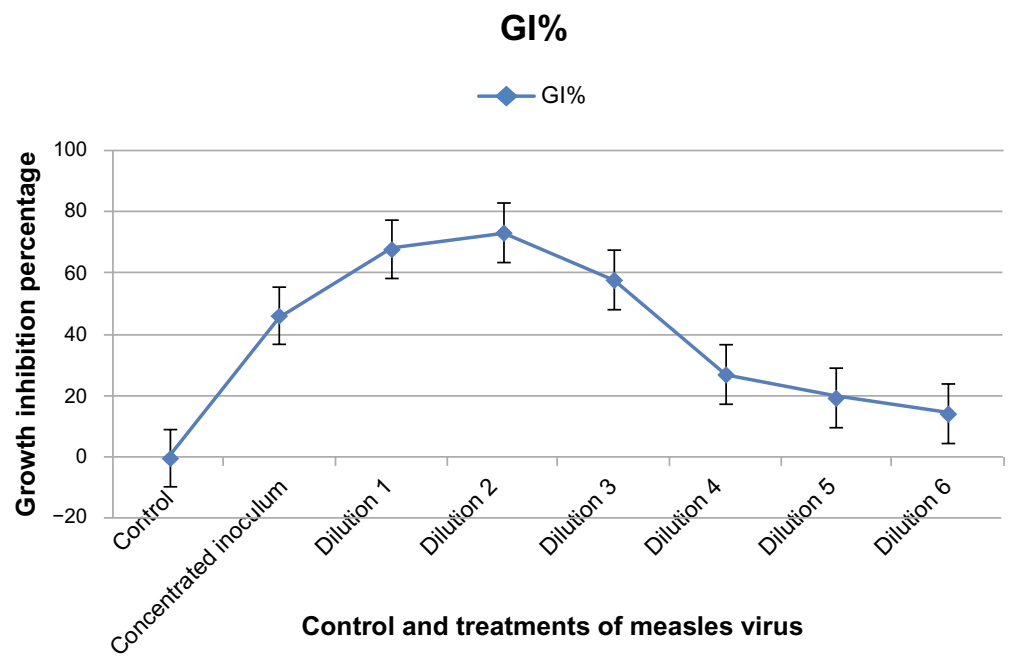

Figure 9 Cytotoxic effect of concentrated and diluted inoculum of measles virus on the glioblastoma cell line after 72 hours of infection. Abbreviation: Gl\%, growth inhibition percentage. 


\section{GI\%}

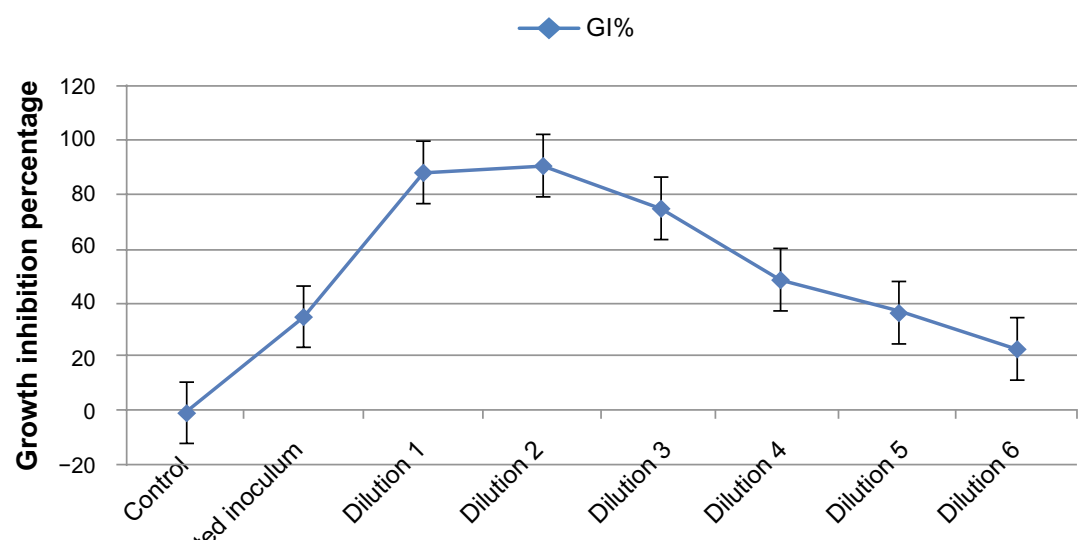

Control and treatments of measles virus

Figure 10 Cytotoxic effect of concentrated and diluted inoculum of measles virus on the glioblastoma cell line after 120 hours of infection. Abbreviation: Gl\%, growth inhibition percentage.

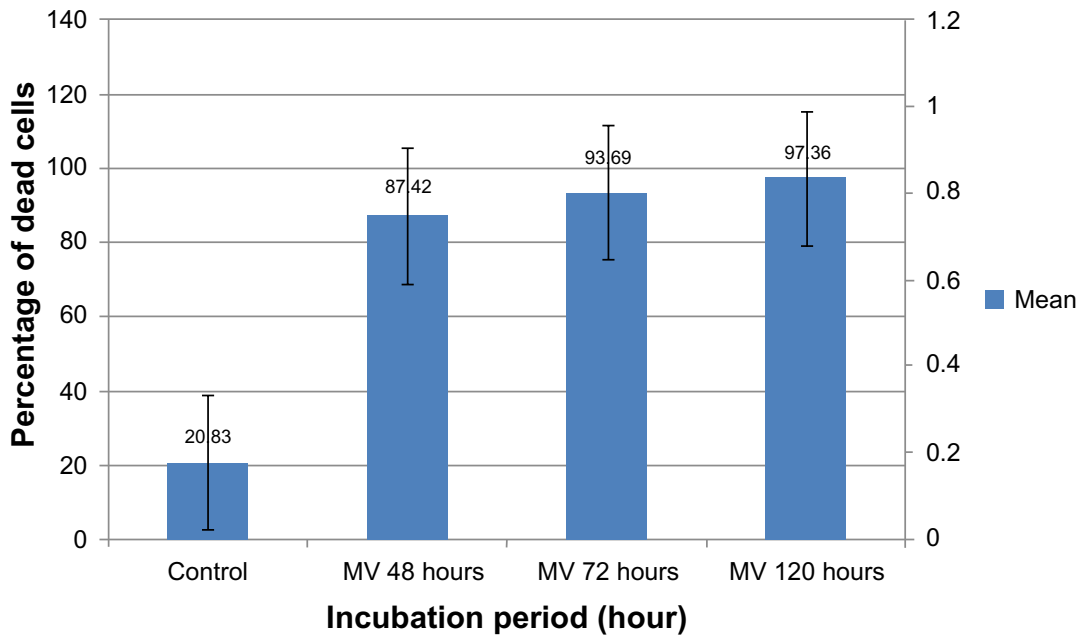

Figure II Rhabdomyosarcoma cell line infected with measles virus at different incubation periods. Abbreviation: MV, measles virus.

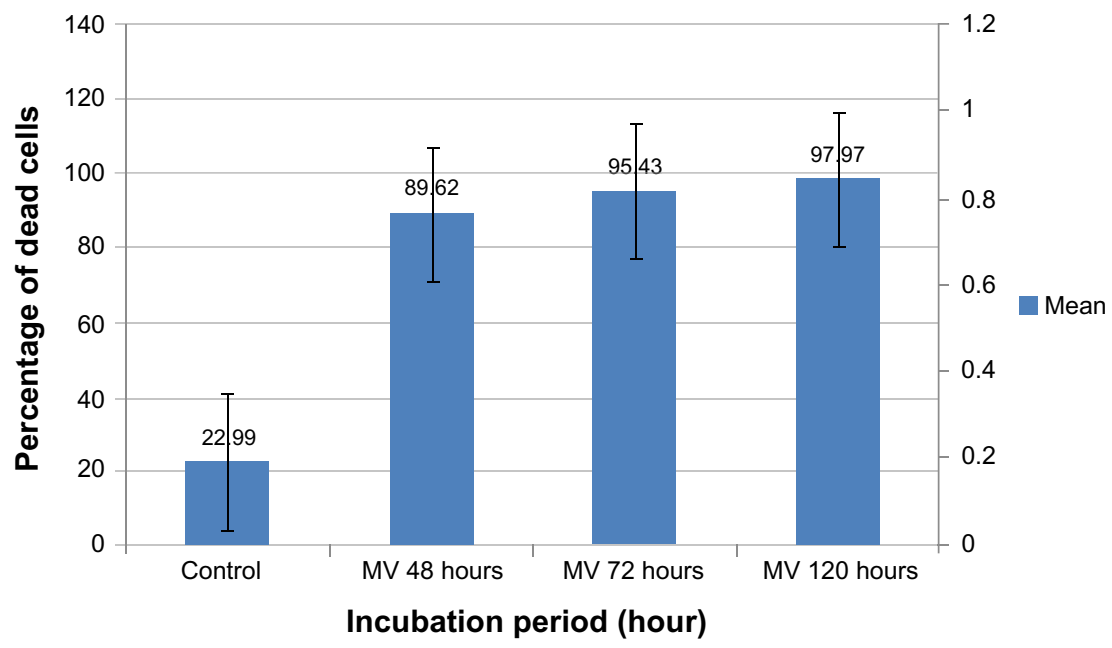

Figure 12 Glioblastoma cell line infected with measles virus at different incubation periods. Abbreviation: MV, measles virus. 
Figure 10 showed that the cytotoxic effect of MV on GBM cells after 120 hours of exposure was significantly higher $(P \leq 0.05)$ on the growth of the GBM cell line at dilutions 1, 2, and 3 compared with the control, with growth inhibition percentages of $87.817 \%, 90.101 \%$, and $74.746 \%$, respectively. A concentrated inoculum of MV showed a significant cytotoxic effect when compared with the control, with a growth inhibition percentage of $35.279 \%$. The cytotoxic inhibition rate was significantly decreased when the dilution increased, with a significant effect at dilutions 4,5 , and 6 , with a growth inhibition percentage of $48.477 \%, 36.421 \%$, and $23.477 \%$, respectively.

\section{Mitochondrial permeability transition apoptosis test}

Results, as shown in Figure 11, indicate that MV induces apoptosis in RD cell lines stained with MitoCapture ${ }^{\mathrm{TM}}$ (US Biological), and the means percentages of apoptotic cells were significantly higher $(87.42 \%, 93.69 \%$, and $97.36 \%$, respectively) after 48,72 , and 120 hours of infection in comparison with uninfected RD cells (20.83\%).

Moreover, the means percentage of apoptotic cells was significantly lower in uninfected GBM cells (22.99\%). Significant differences were recorded in GBM cells infected with MV after 48, 72, and 120 hours of infection (89.62\%, $95.43 \%$, and $97.97 \%$, respectively) (Figure 12). In addition, the amounts of green and red fluorescence in the cells were statistically analyzed and showed as histograms using ImageJ program (National Institutes of Health) (Figures 13, 14 and 15).

\section{Discussion}

Results showed that the live attenuated MV vaccine successfully passaged and replicated on the Iraqi GBM tumor cell line ANGM5, African green monkey kidney cells (Vero cell line), and RD cells. Vero cells are susceptible to infection by $M V .{ }^{18}$ It is known that viruses enter through natural measles receptor CD46 and spread by cell-cell fusion, causing giant syncytia formation and killing the tumor cells. ${ }^{19}$ The results of this study showed that MV Schwarz strain efficiently kills tumor cells and causes an obvious cytopathic effect on infected cell lines 72-120 hours after infection. The cytopathic effect of MV begins after the viral $\mathrm{H}$ protein interacts with its receptor (CD46) on a target cell. This interaction triggers conformational changes in the viral fusion protein, which lead to fusion of the viral and cell plasma membranes, allowing the viral nucleoprotein
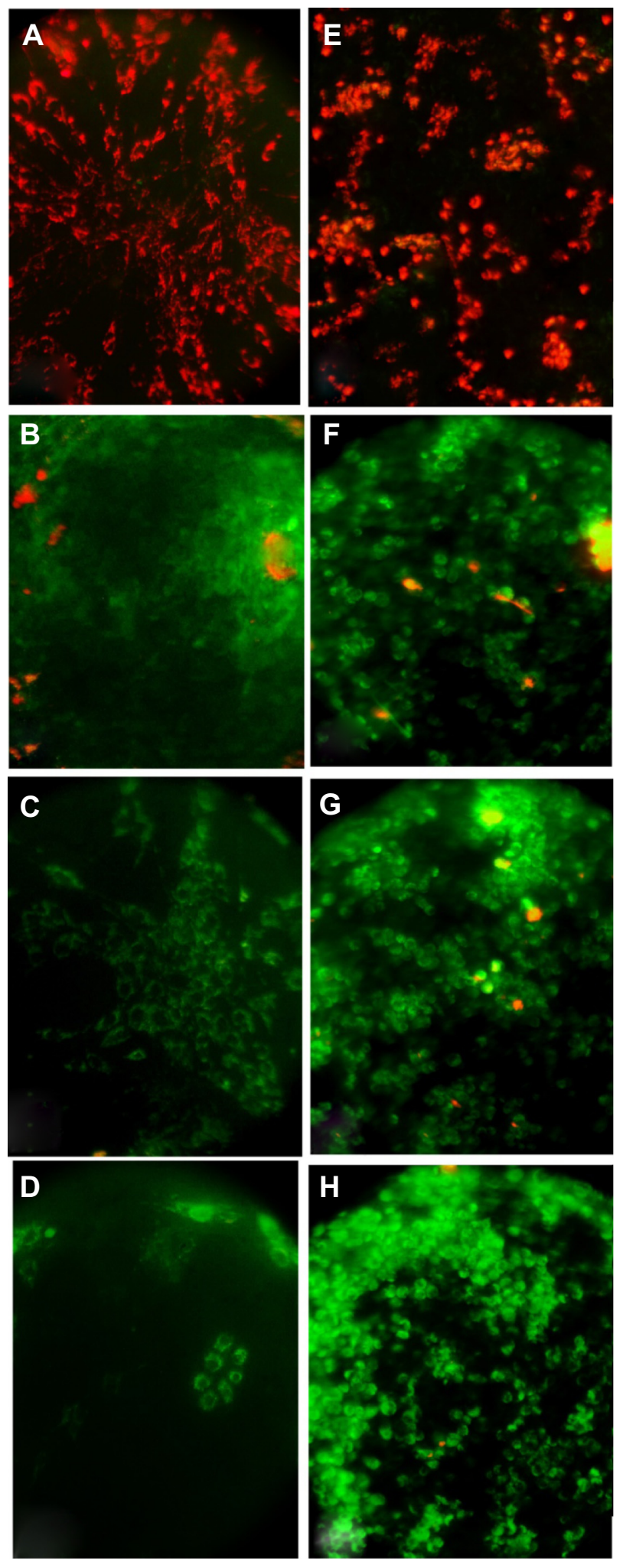

Figure 13 Mitochondrial permeability transition apoptosis test on tumor cell lines. Notes: (A) Glioblastoma (GBM) cells uninfected with measles virus. (B) GBM cells infected with measles virus after 48 hours. (C) GBM cells infected with measles virus after 72 hours. (D) GBM cells infected with measles virus after 120 hours. (E) Rhabdomyosarcoma (RD) cells uninfected with measles virus. (F) RD cells infected with measles virus after 48 hours. (G) RD cells infected with measles virus after 72 hours. (H) RD cells infected with measles virus after 120 hours. All tumor cells were stained with MitoCapture ${ }^{\mathrm{TM}}$ (US Biological, Salem, MA, USA) and viewed through a fluorescence microscope, $40 x$. 
A
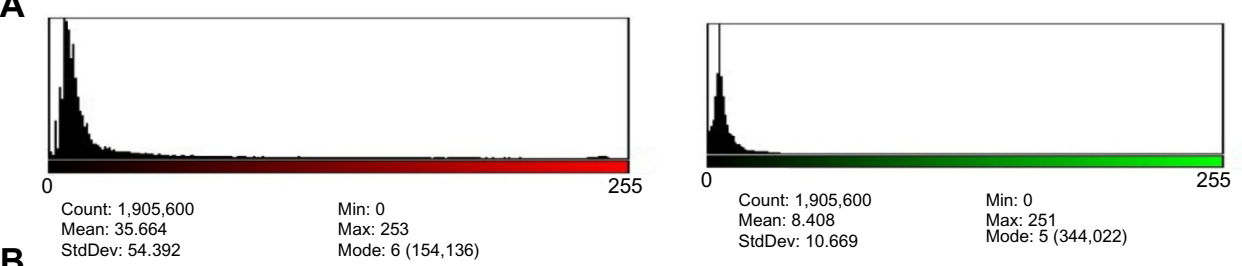

B
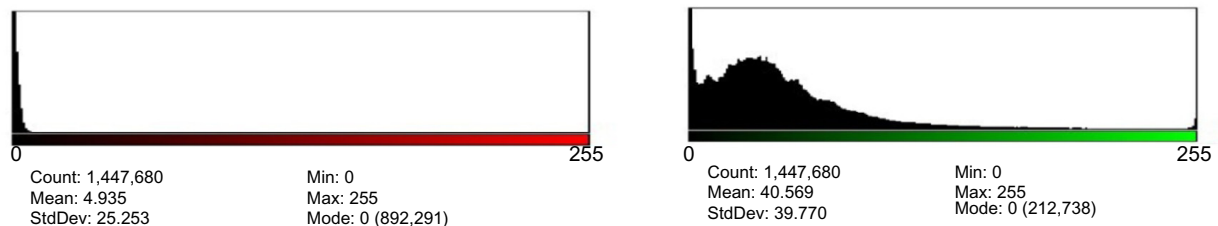

C
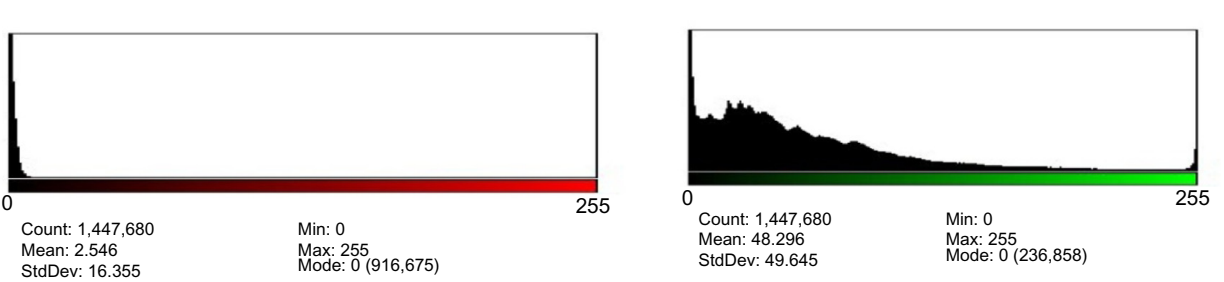

D StdDev: 16.355

Max: 255
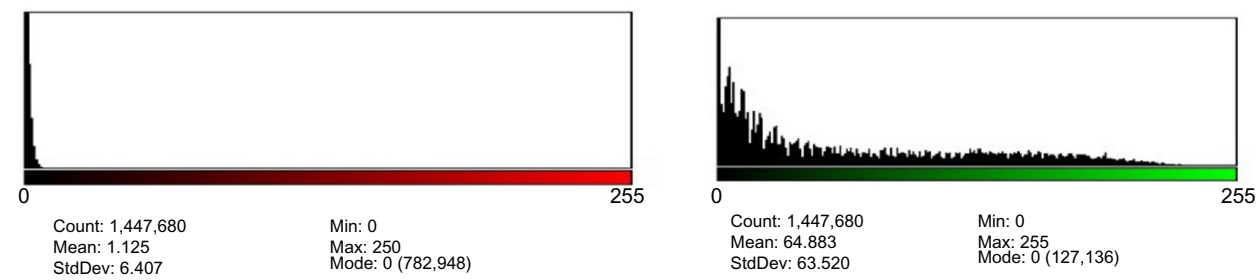

Figure 14 Histogram of images analysis of mitochondrial permeability transition apoptosis test of rhabdomyosarcoma (RD) cell line, 40x.

Notes: (A) RD cells uninfected with measles. The mean of red color of nonapoptotic cells was 35.66 . The mean of green color of apoptotic cells was 8.40 , so the percentage of apoptotic cells was $23.5 \%$. (B) RD cell line infected with measles virus after 48 hours. The mean of red color for nonapoptotic cells was 4.93 . The mean of green color for apoptotic cells was 40.56 , so the percentage of red color viable cells was $12.15 \%$. (C) RD cell infected with measles virus after 72 hours. The mean of red color for nonapoptotic cells was 2.54 . The mean of green color for apoptotic cells was 48.29 , so the percentage of viable cells was $5.25 \%$. (D) RD cell infected with measles virus after I20 hours. The mean of red color for nonapoptotic cells was I.I25. The mean of green color for apoptotic cells was 64.883 , so the percentage of viable cells was I.73\%.

Abbreviations: StdDev, standard deviation; Min, minimum; Max, maximum.

complex to enter into the cell. The $\mathrm{H}$ protein interacts with CD46 on neighboring cells and can trigger membrane fusion between cells. As the expression of the viral $\mathrm{H}$ and fusion proteins increases, the probability that an infected cell will fuse with a neighboring tumor cell increases. Once two cells fuse, there is an effective decrease in the concentration of viral proteins expressed on the cell surfaces, and therefore, there is a delay in the spread of fusion until additional proteins are expressed on the surface. In time, this spread of cell-to-cell fusion leads to the formation of giant cell syncytia, which normally die after a few days. ${ }^{20,21}$ Infected cells that have been incorporated into syncytia stop replicating and do not contribute to further growth of the tumor population. In addition, once infected cells die, they might release free virus particles that can infect surrounding cells. ${ }^{22}$

Results of a hemadsorption test showed that the cells infected with virus for 72 hours have a positive result because MV contains a surface glycoprotein known as hemagglutinin. These cells are capable of binding RBCs. When viruses replicate on cell culture, $\mathrm{H}$ molecules appear on the cell surface. If human RBCs are added to the cell culture in which the virus is replicating, they will adhere to the cell sheet in a phenomenon known as hemadsorption. The presence of hemadsorbing viruses can therefore be detected several days before a cytopathic effect becomes apparent; ${ }^{23}$ uninfected cells have negative results on the hemadsorption test.

In this study, the result of a cytotoxicity test of live attenuated MV on human cancer cells (RD and GBM) after 72 and 120 hours showed that concentrated inoculums and higher dilutions of MV have a low cytotoxic inhibition rate, and the low dilutions of MV caused a higher cytotoxic inhibition rate. This result highlights the competition among viral replication, tumor cell growth, and the death rate of infected tumor cells. ${ }^{24}$ Dingli et $\mathrm{al}^{25}$ reported that the virus, 
A
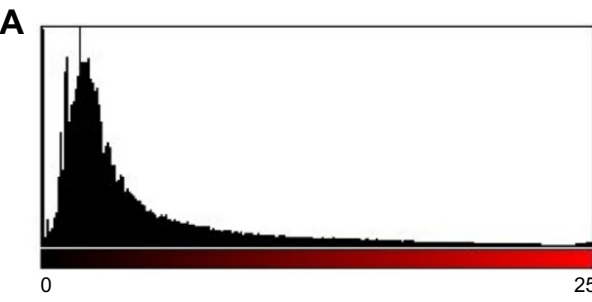

Count: $1,447,680$

Mean: 44.979

$\mathbf{B}$

Min: 0

Max: 255

Mode: $17(46,616)$

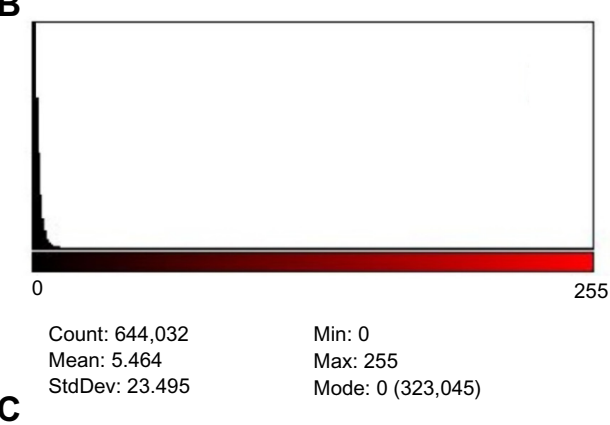

C

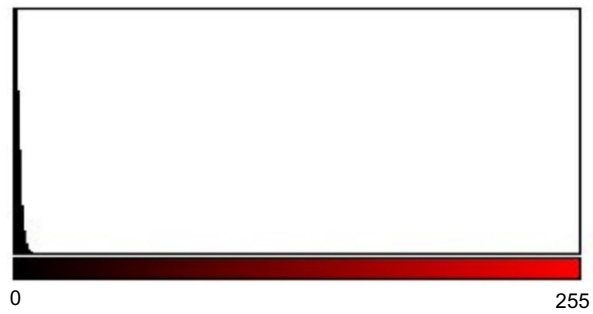

Count: $1,447,680$

Mean: 1.042

StdDev: 3.760

D

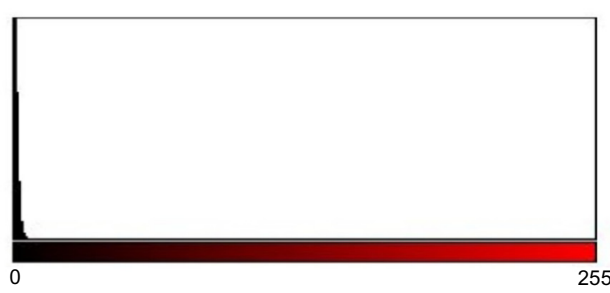

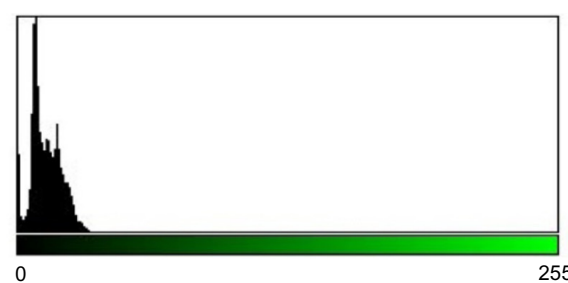

Count: $1,447,680$

Mean: 12.905

StdDev: 6.982

Max: 183

Mode: $17(144,245)$

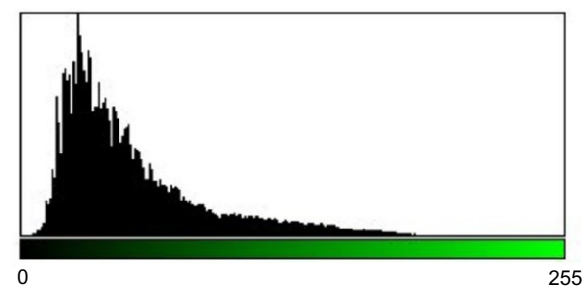

Count: $644,032 \quad$ Min: 0

Mean: $52.663 \quad$ Max: 255

StdDev: $35.847 \quad$ Mode: $26(17,271)$

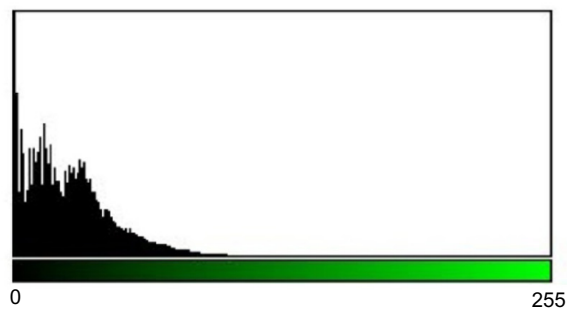

Count: $1,447,680$

Mean: 23.090

StdDev: 21.663

Min: 0

Max: 193

Mode: $0(246,355)$

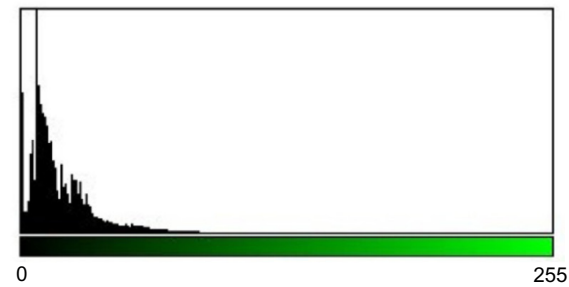

Count: $1,447,680 \quad$ Min: 0

Mean: $21.420 \quad$ Max: 196

StdDev: $23.714 \quad$ Mode: $7(116,396)$

StdDev: $1.214 \quad$ Mode: $0(893,730)$

Figure 15 Histogram of images analysis of mitochondrial permeability transition apoptosis test of Glioblastoma (GBM) cell line, 40×.

Notes: (A) GBM cells uninfected with measles virus. The mean of red color for nonapoptotic cells was 44.979. The mean of green color for apoptotic cells was I2.90, so the percentage of apoptotic cells was $\mathbf{2 8 . 6 8 \%}$. (B) GBM cells infected with measles virus after 48 hours. The mean of red color for nonapoptotic cells was 5.46 . The mean of green color for apoptotic cells was 52.66 , so the percentage of viable cells was $10.36 \%$. (C) GBM cells infected with measles virus after 72 hours. The mean of red color for nonapoptotic cells was I.04. The mean of green color for apoptotic cells was 23.09 , so the percentage of viable cells was $4.50 \%$. (D) GBM cells infected with measles virus after I20 hours. The mean of red color for nonapoptotic cells was $\mathbf{0 . 6 2}$. The mean of green color for apoptotic cells was 21.42 , so the percentage of viable cells was $2.89 \%$.

Abbreviations: StdDev, standard deviation; Min, minimum; Max, maximum.

in high concentration, cannot infect tumor cells because the surface receptors of tumor cells will be saturated with virus ligands. Moreover, Wodarz ${ }^{26}$ reported that very low concentrations of virus that have infected cells are not available to infect additional cells, leading to a potential imbalance in the virotherapy.
Results of the cytotoxic effect and apoptosis of MV showed that the live attenuated MV vaccine has a natural ability to specifically kill a variety of human tumor cells. It exerts its cytopathic effect by fusing infected cells with the surrounding cells, forming multinucleated syncytia, which is followed by cell death by apoptotic or nonapoptotic mechanisms to a variety 
of human tumor cells. ${ }^{27}$ This selectivity results from the entry of MV: attenuated MV enters the cell via receptor CD46, which is overexpressed on tumor cells. ${ }^{28} \mathrm{MV}$ is a lytic virus, and MV replication in tumor cells leads to lysis of cancer cells. In addition, MV induces apoptosis. Zhou et $\mathrm{a}^{29}$ reported that the live-attenuated MV vaccine could potently induce apoptosis in ovarian cancer cells because the live-attenuated MV vaccine possesses antitumor activity against ovarian cancer in vitro through aberrant reactive oxygen species activation-mediated epigenetic silencing of E-cadherin and lays the theoretical foundation for the clinical application of the live-attenuated MV vaccine in the treatment of ovarian cancer. ${ }^{29}$

\section{Conclusion}

MV vaccine strains replicate efficiently in GBM tumor cells as well as in Vero and RD cells and can be further investigated for future use as GBM recommended therapy.

\section{Disclosure}

The authors report no conflicts of interest in this work.

\section{References}

1. Amartya D, Bala NN, Bhattacharjee A. Treatment of glioblastoma multiforme. JPBMS. 2011;12(6).

2. Jemal A, Murray T, Ward E, et al. Cancer statistics, 2005. CA Cancer J Clin. 2005;55(1):10-30.

3. Vanneman M, Dranoff G. Combining immunotherapy and targeted therapies in cancer treatment. Nat Rev Cancer. 2012;12(4):237-251.

4. Verheije MH, Rottier PJ. Retargeting of viruses to generate oncolytic agents. Adv Virol. 2012;2012:798526.

5. Moss WJ, Griffin DE. Global measles elimination. Nat Rev Microbiol. 2006;4(12):900-908.

6. Fielding AK. Measles as a potential oncolytic virus. Rev Med Virol. 2005;15(2):135-142.

7. Peng KW, Hadac EM, Anderson BD, et al. Pharmacokinetics of oncolytic measles virotherapy: eventual equilibrium between virus and tumor in an ovarian cancer xenograft model. Cancer Gene Ther. 2006;13(8): 732-738.

8. Zhang SC, Wang WL, Cai WS, Jiang KL, Yuan ZW. Engineered measles virus Edmonston strain used as a novel oncolytic viral system against human hepatoblastoma. BMC Cancer. 2012;12:427.

9. Al-Shamery A, Yaseen N, Alwan MJ. Study the Antigenic modification of tumor cell surface by NDV infection. Iraqi Journal of Cancer and Medical Genetics. 2009;2(1):95.

10. Al-Shamery AM, Yaseen NY, Alwan MJ. Immunology study for NDV treatment in mice bearing mammary adenocarcinoma tumour. Iraqi $J$ Ca Med Genet. 2011;4:11-21.

Oncolytic Virotherapy

\section{Publish your work in this journal}

Oncolytic Virotherapy is an international, peer-reviewed, open access online journal publishing original research, study protocols, reviews, editorials and commentaries on all aspects of oncolytic virology, namely the application of oncolytic viruses for the treatment of cancer. Specific topics in the journal include: Rationale and theoretical aspects of oncolytic virotherapy including in vitro, in vivo and mathematical

Submit your manuscript here: http://www.dovepress.com/oncolytic-virotherapy-journal
11. Al-Shammari A, Al-Juboury AA, Al-Mukhtar A, Yaseen NY, Ali A. Establishment and characterization of a chemoresistant glioblastoma cell line from an Iraqi patient. Presented at: American Association of Cancer Research Annual Meeting; April; 2014; San Diego, CA.

12. Freshney R. Culture of Animal Cells: A Manual of Basic Technique and Specialized Application. 6th ed. Hoboken, NJ: Wiley-Blackwell; 2010.

13. Al-Shammary A, Hassani HH, Ibrahim UAJ. Newcastle Disease Virus (NDV) Iraqi Strain AD2141 Induces DNA Damage and FasL in Cancer Cell Lines. J Biol Life Sci. 2014;5(1):1-11.

14. Bell DM, Roberts NJ Jr, Madore HP, Hall CB, Simons RL. Hemadsorption focus assay for growth of influenza and parainfluenza viruses in human dermal fibroblasts. Proc Soc Exp Biol Med. 1985;179(3):377-81.

15. Haas C, Ertel C, Gerhards R, Schirrmacher V. Introduction of adhesive and costimulatory immune functions into tumor cells by infection with Newcastle Disease Virus. Int J Oncol. 1998;13(6):1105-1115.

16. Hand AJ, Sun T, Barber DC, Hose DR, MacNeil S. Automated tracking of migrating cells in phase-contrast video microscopy sequences using image registration. J Microsc. 2009;234(1):62-79.

17. Wild TF, Malvoisin E, Buckland R. Measles virus: both the haemagglutinin and fusion glycoproteins are required for fusion. J Gen Virol. 1991;72(Pt 2):439-442.

18. Norrby E, Oxman M. Measles virus. In: Fields BN, Knipe DM, Chanock RM, et al, editors. Fields Virology. New York: Raven Press; 1990:1013-1044.

19. Yanagi Y, Takeda M, Ohno S. Measles virus: cellular receptors, tropism and pathogenesis. J Gen Virol. 2006;87(Pt 10):2767-2779.

20. Peng KW, Ahmann GJ, Pham L, Greipp PR, Cattaneo R, Russell SJ. Systemic therapy of myeloma xenografts by an attenuated measles virus. Blood. 2001;98(7):2002-2007.

21. Peng KW, TenEyck CJ, Galanis E, Kalli KR, Hartmann LC, Russell SJ. Intraperitoneal therapy of ovarian cancer using an engineered measles virus. Cancer Res. 2002;62(16):4656-4662.

22. Bajzer Z, Carr T, Josić K, Russell SJ, Dingli D. Modeling of cancer virotherapy with recombinant measles viruses. J Theor Biol. 2008;252(1): 109-122.

23. Koneman E, Allen S, Janda W, Schreckenberger P, Winn W. Color Atlas and Textbook of Diagnostic Microbiology. 5th ed. Philadelphia: Lippincott Williams \& Wilkins; 1997;1241.

24. Friedman A, Tian JP, Fulci G, Chiocca EA, Wang J. Glioma virotherapy: effects of innate immune suppression and increased viral replication capacity. Cancer Res. 2006;66(4):2314-2319.

25. Dingli D, Cascino MD, Josić K, Russell SJ, Bajzer Z. Mathematical modeling of cancer radiovirotherapy. Math Biosci. 2006;199(1):55-78.

26. Wodarz D. Gene therapy for killing p53-negative cancer cells: use of replicating versus nonreplicating agents. Hum Gene Ther. 2003;14(2): 153-159.

27. Gauvrit A, Brandler S, Sapede-Peroz C, Boisgerault N, Tangy F, Gregoire M. Measles virus induces oncolysis of mesothelioma cells and allows dendritic cells to cross-prime tumor-specific CD8 response. Cancer Res. 2008;68(12):4882-4892.

28. Davis JJ, Fang B. Oncolytic virotherapy for cancer treatment: challenges and solutions. J Gene Med. 2005;7(11):1380-1389.

29. Zhou S, Li Y, Huang F, et al. Live-attenuated measles virus vaccine confers cell contact loss and apoptosis of ovarian cancer cells via ROSinduced silencing of E-cadherin by methylation. Cancer Lett. 2012; 318(1):14-25.

modeling; and practical application and problem solving in the clinic including identification of potential responders through biomarkers and genetic profiling. The manuscript management system is completely online and includes a very quick and fair peer-review system, which is all easy to use. Visit http://www.dovepress.com/ testimonials.php to read real quotes from published authors. 